\title{
ANALISIS DETERMINASI GAYA GAYA KEPEMIMPINAN KEPALA SEKOLAH, MANAJEMEN MUTU, LINGKUNGAN KERJA, DAN KOMITMEN KERJA TERHADAP KEPUASAN KERJA GURU SMA NEGERI 1 MENGWI
}

\author{
Gusti Ketut Putrayana, Anak Agung Gede Agung', I. G. K. Arya Sunu \\ Jurusan Administrasi Pendidikan, Program Pascasarjana \\ Universitas Pendidikan Ganesha \\ Singaraja, Indonesia \\ e-mail: \{ketut.putrayana, gede.agung, arya.sunu\} @pasca undiksha.ac.id
}

\begin{abstract}
Abstrak
Penelitian ini bertujuan untuk mengetahui pengaruh gaya kepemimpinan kepala sekolah, manajemen mutu,lingkungan kerja dan komitmen kerja terhadap kepuasan kerja Di SMA Negeri 1 Mengwi secara terpisah maupun simultan.Populasi penelitian ini adalah seluruh guru Di SMA Negeri 1 Mengwi dengan jumlah sampel sebanyak 70 jumlah guru. Penelitian ini menggunakan rancangan ex-post facto.Data dikumpulkan dengan kuesioner dan lembar observasi. Data dianalisis dengan regresi, korelasi dan analisis determinasi.Hasil penelitian menunjukkan bahwa: (1) Terdapat determinasi yang signifikan gaya kepemimpinan kepala sekolah terhadap kepuasan kerja dengan sumbangan efektif sebesar $17,20 \%$, (2) Terdapat determinasi yang signifikan antara manajemen mutu terhadap kepuasan kerja dengan sumbangan efektif sebesar $31,70 \%$, (3) Terdapat determinasi yang signifikan antara lingkungan kerja terhadap kepuasan kerja dengan sumbangan efektif sebesar $11,70 \%$, (4) Terdapat determinasi yang signifikan antara komitmen kerja terhadap kepuasan kerja dengan sumbangan efektif sebesar $16,50 \%$, dan (5) Terdapat determinasi yang signifikan secara bersama-sama gaya kepemimpinan kepala sekolah, manajemen mutu, lingkungan kerja, dan komitmen kerja terhadap kepuasan kerja sebesar $76,90 \%$. Dengan demikian keempat variabel di atas dapat dijadikan prediktor kecenderungan tingkat kepuasan kerja guru di SMA Negeri 1 Mengwi.
\end{abstract}

Kata kunci: gaya kepemimpinan kepala sekolah, manajemen mutu, lingkungan kerja, komitmen kerja, kepuasan kerja.

\section{Abstact}

The aim of the research is to recognize the influence of the typical leadership of the headmaster, management quality, work environment, and work commitment. Toward the work satisfaction at SMA Negeri 1 Mengwi separately or simultaneously. Population research is that all teacher of SMA Negeri 1 Mengwi with 70 teachers as sample. This research uses Ex-post facto program. The data was collected by applying questioner and observation work sheet. The data has been analyzed with regression correlation and determination analysis. The result of research shows that: (1) There is significant determination Typical Leadership of the headmaster toward the work satisfaction with effective donation of $17,20 \%$, (2) There is significant determination between Quality management to work satisfaction with effective donation as big as $31,70 \%$, (3) There is significant determination between work environment to work satisfaction with the effective donation as big as $11,70 \%$, (4) There is significant determination between work commitment toward work satisfaction with effective donation as big as $16,50 \%$, and (5) There is significant determination simultaneously the headmaster typical leadership, quality management, work environment, and work commitment toward work satisfaction with the contribution as big as $76,90 \%$. Therefore, the above four variables can be used as predictor tendency level of work satisfaction of the teachers of SMA Negeri 1 Mengwi.

Keyword: $\quad$ The Typical Leadership of The School Principal, Management quality, work environment, work commitment, work satisfaction.

\section{PENDAHULUAN}

Peningkatan kualitas sumber daya manusia merupakan kenyataan yang harus dilakukan secara terencana, terarah, intensif, efektif dan efesien dalam mengahadapi era globalisasi yang sangat komprensif. Peningkatan kualitas pendidikan merupakan suatu proses terintegrasi dalam peningkatan sumber daya manusia itu sendiri. Pentingnya 
pengembangan sistem pendidikan yang berkualitas perlu lebih ditekankan, karena berbagai indikator menunjukkan bahwa pendidikan yang ada belum mampu menghasilkan sumber daya sesuai dengan perkembangan masyarakat dan kebutuhan pembangunan.

Guru adalah salah satu komponen manusiawi dalam proses belajar mengajar, yang ikut berperan dalam usaha pembentukan sumber daya manusia yang potensial di bidang pembangunan. Oleh karena itu, guru yang merupakan salah satu unsur di bidang kependidikan harus berperan secara aktif dan menempatkan kedudukannya sebagai tenaga profesional, sesuai dengan tuntutan masyarakat yang semakin berkembang. Peningkatan mutu pendidikan ditentukan oleh kesiapan sumber daya manusia yang terlibat dalam proses pendidikan. Guru merupakan salah satu faktor penentu tinggi rendahnya mutu hasil pendidikan mempunyai posisi strategis maka setiap usaha peningkatan mutu pendidikan perlu memberikan perhatian besar kepada peningkatan guru baik dalam segi jumlah maupun mutunya.

Guru adalah figur manusia sumber yang menempati posisi dan memegang peran penting dalam pendidikan. Ketika semua orang mempersoalkan masalah dunia pendidikan figur guru mesti terlibat dalam agenda pembicaraan terutama yang menyangkut persoalan pendidikan formal di sekolah. Pendidik atau guru merupakan tenaga profesional yang bertugas merencanakan dan melaksanakan proses pembelajaran, menilai hasil pembelajaran, melakukan pembimbingan dan pelatihan, serta melakukan penelitian dan pengabdian kepada masyarakat, terutama bagi pendidik pada perguruan tinggi. Hal tersebut tidak dapat disangkal kerana lembaga pendidikan formal adalah dunia kehidupan guru.

Tenaga kependidikan mempunyai peran yang sangat strategis dalam pembentukan pengetahuan, ketrampilan, dan karakter peserta didik. Oleh karena itu, tenaga kependidikan yang professional akan melaksanakan tugasnya secara professional sehingga menghasilkan tamatan yang berkualitas. Menjadi tenaga kependidikan yang profesional tidak akan terwujud begitu saja tanpa adanya upaya untuk meningkatkannya. Adapun salah satu cara untuk mewujudkannya adalah dengan pengembangan profesionalisme yang membutuhkan dukungan dari pihak yang mempunyai peran penting, dalam hal ini adalah kepala sekolah. Kepala sekolah merupakan pemimpin pendidikan yang sangat penting karena kepala sekolah berhubungan langsung dengan pelaksanaan program pendidikan di sekolah.

Gaya kepemimpinan adalah cara yang gunakan pemimpin dalam mempengaruhi pengikutnya. Menurut Thoha (1995) gaya kepemimpinan merupakan norma perilaku seseorang pada saat orang tersebut mencoba mempengaruhi perilaku orang lain seperti yang ia lihat. Dalam hal ini usaha menselaraskan persepsi di antara orang yang akan mempengaruhi perilaku dengan yang akan dipengaruhi menjadi amat penting kedudukannya.

Kepala sekolah sebagai pimpinan tertinggi yang sangat berpengaruh dan menentukan kemajuan sekolah harus memiliki kemampuan administrasi, memiliki komitmen tinggi, dan luwes dalam melaksanakan tugasnya. Kepemimpinan kepala sekolah yang baik harus dapat mengupayakan peningkatan kinerja guru melalui program pembinaan kemampuan tenaga kependidikan. Oleh karena itu kepala sekolah harus mempunyai kepribadian atau sifat-sifat dan kemampuan serta keterampilan-keterampilan untuk memimpin sebuah lembaga pendidikan. Dalam perannya sebagai seorang pemimpin, kepala sekolah harus dapat memperhatikan kebutuhan dan perasaan orang-orang yang bekerja sehingga kinerja guru selalu terjaga. Dalam pelaksanaan tugas mendidik, guru memiliki sifat dan perilaku yang berbeda, ada yang bersemangat dan penuh tanggung jawab, juga ada guru yang dalam melakukan pekerjaan itu tanpa dilandasi rasa tanggung jawab, selain itu juga ada guru yang sering membolos, datang tidak tepat pada waktunya dan tidak mematuhi perintah. Kondisi guru seperti itulah yang menjadi permasalahan di setiap lembaga pendidikan formal. Dengan adanya guru yang mempunyai kepuasan kerja rendah, sekolah akan sulit untuk mencapai hasil seperti yang diharapkan dan guru. 
Peran kepala sekolah yang tidak dijalankan secara efektif dapat pula berdeterminasi terhadap kerja para bawahannya dalam melaksanakan tugas profesinya. Karena yang memiliki peluang untuk memdeterminasi dalam kepemimpinan organiasi atau lembaga pendidikan khususnya sekolah adalah pimpinan (kepala sekolah) atau manajer itu sendiri. Dalam suatu organisasi sekolah ditentukan oleh iklim organisasi, terutama dalam organisasi yang diciptakan oleh pola hubungan antar pribadi yang berlaku dalam lingkungan organisasi sekolah tersebut.

Manajemen mutu juga diduga berpengaruh terhadap kepuasan kerja guru. Manajemen mutu adalah suatu cara dalam mengelola suatu organisasi yang bersifat komprehensif dan terintegrasi yang diarahkan dalam rangka memenuhi kebutuhan pelanggan secara konsisten dan mencapai peningkatan secaraterus menerus dalam setiap aspek aktivitas organisasi. Sasaran yang dituju dari manajemen mutu adalah meningkatkan mutu pekerjaan, memperbaiki prodiktivitas dan efisiensi melalui perbaikan kinerja dan peningkatan mutu kerja agar menghasilkan produk yang memuaskan atau memenuhi kebutuhan pelanggan. Jadi, manajemen mutu bukanlah seperangkat peraturan dan ketentuan yang kaku yang harus diikuti, melainkan seperangkat prosedur proses untuk memperbaiki kinerjadan meningkatkan mutu kerja.

Manajemen Mutu adalah aspek-aspek dari fungsi manajemen keseluruhan yang menetapkan dan menjalankan kebijakan mutu suatu perusahaan/organisasi. Dalam rangka mencukupkan kebutuhan pelanggan dan ketepatan waktu dengan anggaran yang hemat dan ekonomis, seorang manager proyek harus memasukkan dan mengadakan pelatihan management kualitas. Hal hal yang menyangkut kualitas yang di maksud diatas adalah Produk / pelayanan / proses pelaksanaan dan Proses management proyek itu sendiri.

Manajemen mutu dalam pendidikan merupakan cara dalam mengatur semua sumber daya pendidikan, yang diarahkan agar semua orang yangterlibat di dalamnya melaksanakan tugas dengan penuh semangat danberpartisipasi dalam perbaikan pelaksanaan pekerjaan sehingga menghasilkan jasa yang sesuai bahkan melebihi harapan pelanggan.

Manajemen mutu merupakan sebuah filsafat dan budaya organisasi yang menekankan kepada upaya menciptakan mutu yang konstan melalui setiap aspek dalam kegiatan organisasi. Manajemen mutu membutuhkan pemahaman mengenai sifat mutu dan sifat sistem mutu serta komitmen manajemen untuk bekerja dalm berbagai cara. Manajemen mutu sangat memerlukan figure pemimpin yang mampu memotivasi agar seluruh anggota dalam organisai dapat memberikan konstribusi semaksimal mungkin kepada organisasi sehingga kepuasan kerja guru meningkat. Hal tersebut dapat dibangkitkan melalui pemahaman dan penjiwaan secara sadar bahwa mutu suatu produk atau jasa tidak hanya menjadi tanggung jawab pimpinan, tetapi menjadi tanggung jawab seluruh anggota dalam organisasi.

Lingkungan kerja juga berpengaruh terhadap kepuasan kerja guru. Lingkungan tempat kerja adalah segala sesuatu yang ada di sekitar pekerja dan yang dapat mempengaruhi dirinya dalam menjalankan tugas - tugas yang dibebankan. Misalnya kebersihan, musik dan lain-lain (Nitisemito,1996: 109). Pendapat lain menyatakan bahwa lingkungan fisik adalah semua keadaan yang terdapat di sekitar tempat kerja, akan mempengaruhi pegawai baik secara langsung maupun secara tidak langsung (Sedarmayanti 1996:21).

Steers (1985: 118) menjelaskan bahwa membahas tentang sifat-sifat dan konsep iklim organisasi, kita sebenarnya telah membicarakan tentang sifat dan ciri-ciri lingkungan kerja. Lingkungan kerja di dalam suatu organisasi/perkantoran sangat penting untuk diperhatikan oleh manajemen kantor. Penyusunan suatu sistem perencanaan yang baik tidak akan dapat dilaksanakan dengan efektif apabila tidak didukung dengan lingkungan kerja yang memuaskan di dalam organisasi yang bersangkutan. Segala mesin dan peralatan yang dipasang dan digunakan di dalam kantor (meskipun mempergunakan teknologi yang 
laing baru) tersebut tidak akan banyak berarti apabila para karyawan tidak dapat bekerja dengan baik yang disebabkan karena faktor lingkungan kerja yang memenuhi persyaratan yang ditentukan. Walaupun lingkungan kerja tidak berfungsi sebagai mesin dan peralatan produksi yang langsung memproses bahan menjadi produk, namun pengaruh dari lingkungan kerja ini akan terasa di dalam proses produksi yang dilaksanakan oleh organisasi yang bersangkutan.

Lingkungan kerja merupakan suatu kondisi atau keadaan yang mempunyai pengaruh yang besar terhadap organisasi apakah itu mencakup pengaturan tempat kerja seperti penerangan, kebersihan, sirkulasi udara, pengaturan warna, kebisingan, dan keamanan kerja, baik itu langsung maupun tidak langsung mempengaruhi kepuasan kerja guru.

Disamping gaya kepemimpinan kepala sekolah, manajemen mutu, dan lingkungan kerja, komitmen kerja juga berpengaruh terhadap kepuasan kerja guru. Untuk menjadi pembelajar sejati seorang guru sudah sewajarnya memiliki komitmen kerja yang tinggi. Komitmen ini agar benar-benar tumbuh sehingga secara alami menjadi mesin pembelajaran dan dia belajar sepanjang waktu, karena dalam proses belajar-mengajar guru sebagai pemeran utama. Dimana guru harus mampu mewujudkan proses pembelajaran yang efektif dan efisien, dapat mengantarkan siswa memperoleh hasil belajar yang optimal. Dengan demikian maka kepuasan kerja guru juga akan meningkat.

Menjadi pembelajar harus merupakan agenda pribadi setiap guru dan komitmen tersebut terus dijaga agar tetap pada koridornya. Ketika guru menjadi pembelajar sejati siswapun akan relatif mudah didorong menjadi belajar. Asumsinya, upaya guru mengubah perilaku siswa akan jauh lebih mudah dengan memberikan contoh ketimbang hanya bisa menyarankan untuk berubah. Siswa akan jauh lebih mudah diajarkan dengan contoh secara dewasa ketimbang hanya diperintah. Jadi keberhasilan proses pembelajaran sangat ditentukan oleh kemampuan guru dalam mengelola pembelajaran.

Komitmen kerja dalam proses pembelajaran adalah berlangsungnya proses belajar mengajar di kelas yang merupakan inti dari kegiatan pendidikan di sekolah. Dalam hal ini kemampuan kerja guru dalam mengelola proses pembelajaran adalah kesanggupan atau kecakapan para guru dalam menciptakan suasana komunikasi yang edukatif antara guru dan peserta didik yang mencakup segi kognitif, afektif, dan psikomotor.

Lima pilar utama yang mutlak diperlukan seorang guru untuk bisa dikatakan memiliki komitmen kerja menjadi guru pembelajaran sejati (Sudarwan,2011:67-72) :

1. Rasa ingin tahu, ini merupakan awal mula seorang guru untuk menjadi manusia yang berpengetahuan dan memiliki rasa ingin tahu yang tinggi adalah pembelajaran sejati.

2. Optimisme, inilah model dasar guru untuk tidak mudah menyerah dengan aneka keadaan. Adakalanya, bahkan mungkin banyak terjadi karena pesimis, guru tiba-tiba menghentikan usaha atau perjuangannya ketika sesungguhnya keberhasilan itu sudah sangat dekat untuk dicapai.

3. Keiklasan, guru-guru yang ikhlas nyaris tidak mengenal lelah. Dia selalu bergairah pada setiap keadaan. Banyak siasat, strategi, atau akal baru yang dihasilkan ketika dia berpikir dan memutuskan untuk berbuat. Selalu muncul energi kedua dari dirinya, ketika dia sudah mulai merasa kelelahan tatkala masih diperlukan waktu cukup panjang dan energi cukup besar untuk menyelesaikan tugas pekerjaan. Sebaliknya guru-guru yang tidak ikhlas, akan mencari argumen untuk melegetimasi argumen "tidak mungkin" yang diucapkan. Otot-otonya pun kendor semua, karena otaknya mengintruksi seperti itu.

4. Komitmen, begitu banyak guru bekerja dalam format "keras kerak" yang tersiram air sedikit demi sedikit menjadi lembek, tergoda dengan hal baru dan akhirnya meninggalkan keputusan lama yang telah dibuat. Untuk mencoba hal baru, bukankah ada petani yang ketika banyak orang menanam karet dia ikut pula menanam. Ketika banyak orang menanam kelapa sawit dia pun ikut pula menanam kelapa sawit dengan memangkas karet yang baru tumbuh. Ketika banyak orang menanam coklat dia juga ikut menanam 
coklat dengan memangkas kelapa sawit yang baru tumbuh dan berumur beberapa tahun. Keinginannya yang selalu mengikuti arus orang lain, padahal lahan yang dimilikinya terbatas malah menghantarkannya pada kegagalan. Begitu juga seorang guru yang tidak memiliki komitmen untuk benar-benar bisa menjadi guru yang sejati. Hanya akan memunculkan keluhan-keluhan dalam melaksanakan tugas pokoknya dalam proses belajar-mengajar.

5. Pandangan visioner, artinya pandangan jauh kedepan melebihi batas pemikiran orang kebanyakan. Guru yang termasuk kelompok ini jarang tergoda untuk melakukan apa saja demi hasil yang instan, mengejar target jangka pendek dengan mengorbankan jangka panjang.

Berdasarkan latar belakang yang diuraikan di atas, dapat diketahui bahwa ada hubungan-hubungan antara gaya kepemimpinan kepala sekolah, manajemen mutu, ligkungan kerja, dan komitmen kerja terhadap kepuasan kerja guru, baik secara sendirisendiri maupun bersama-sama. Akan tetapi bagaimana pengaruhnya dan seberapa besar kontribusinya perlu dilakukan penelitian lebih jauh. Untuk itulah penelitian ini penting dilakukan. Maka peneliti dipandang perlu dilakukan penelitian untuk membandingkan seberapa jauh gaya kepemimpinan kepala sekolah, manajemen mutu, ligkungan kerja, dan komitmen kerja terhadap kepuasan kerja guru dengan mengangkat judul penelitian: "Analisis determinasi gaya kepemimpinan kepala sekolah, manajemen mutu, ligkungan kerja, dan komitmen kerja terhadap kepuasan kerja guru SMA Negeri 1 Mengwi

Berdasarkan penjelasan di atas, penulis menyimpulkan ada banyak faktor yang berdeterminasi terhadap kepuasan kerja. Namun penulis dalam penelitian ini memfokuskan untuk meneliti dan mempelajari empat hal utama yang berdeterminasi terhadap kinerja seorang guru di dalam mengelola pembelajaran di sekolah, yaitu gaya kepemimpinan kepala sekolah, manajemen mutu yang dilakukan oleh kepala sekolah, lingkungan kerja yang dimiliki oleh para guru dan komitmen kerja yang berkembang di lingkungan guru maupun masyarakat sekolah.

Dari beberapa gejala tersebut penulis merasa tertarik untuk mencari hubungan antara beberapa indikator yang mempengaruhi kepuasan kerja SMP negeri di Kabupaten Tabanan. Dalam hal ini penulis akan mengkaji "Kontribusi Gaya kepemimpinan kepala sekolah, Manajemen mutu Dan Komitmen kerja Terhadap Kepuasan kerja SMP Negeri SeKabupaten Tabanan".

\section{METODE PENELITIAN}

Penelitian ini adalah termasuk jenis penelitian korelasional. Penelitian ini mengungkapkan hubungan dua variabel, yakni faktor gaya kepemimpinan kepala sekolah, manajemen mutu, lingkungan kerja, dan komitmen kerja sebagai variabel bebas $(\mathrm{x})$, dan kepuasan kerja ditempatkan sebagai variabel terikat (y).

Mengingat variabel-variabel tersebut telah ada dan telah terjadi sebelumnya tanpa memerlukan perlakuan dari penelitian, maka penelitian inbersifat "ex post facto". Sudjana (1989:71) mengemukakan "ex post facto" Artinya sesudah fakta, "ex post facto" sebagai metode penelitian menunjuk kepada perlakuan atau manipulasi variable bebas (x) telah terjadi sebelumnya, sehingga peneliti tidak perlu memberikan perlakuan lagi, tinggal melihat efeknya pada variabel terikat $(\mathrm{y})$.

Dengan demikian dapat dikemukakan bahwa desain atau rancangan yang digunakan dalam penelitian ini adalah rancangan penelitian korelasional dengan pendekatan "ex post facto". Oleh sebab itu semua variabel bebas $(x)$ tidak diberikan perlakuan tetapi diukur bersama-sama dengan variabel terikat $(y)$.

Populasi penelitian ini adalah semua guru SMA Negeri 1 mengwi dengan jumlah 70 orang. Pengambilan sampel dilakukan dengan teknik sensus recearch sehingga jumlah sampel 70. Penelitian ini menggunakan rancangan ex-post facto. Data dikumpulkan dengan 
kuesioner dan lembar observasi. Data dianalisis dengan regresi, korelasi dan analisis determinasi.

Data dikumpulkan dengan metode observasi, dokumentasi dan kuesioner meliputi : Gaya kepemimpinan kepala sekolah $\left(X_{1}\right)$, Manajemen mutu $\left(X_{2}\right)$, lingkungan kerja $\left(X_{3}\right)$, Komitmen kerja $\left(\mathrm{X}_{4}\right)$, dan variabel terikatnya adalah Kepuasan kerja $(\mathrm{Y})$.

untuk memenuhi kualitas isinya, terlebih dahulu dilakukan expert judgment oleh dua pakar guna mendapatkan kualitas tes yang baik. setelah itu dilakukan uji coba instrument untuk mengetahui kesahihan (validitas dan keterandalan (reliabilitas) dengan bantuan program Microsoft Excel.

Data penelitian ini dianalisis secara bertahap, meliputi : deskripsi data, uji prasyarat, dan uji hipotesis. Uji prasyarat yang dilakukan adalah uji normalitas sebaran data, uji linieritas, uji multikolinieritas, uji autokorelasi, dan uji heterokedastisitas. pengujian prasyarat analisis seluruhnya menggunakan bantuan program SPSS 16.0 for Windows.

Hipotesis dalam penelitian ini, yaitu : 1) terdapat determinasi gaya kepemimpinan kepala sekolah terhadap kepuasan kerja pada Guru SMA Negeri 1 mengwi, 2) terdapat determinasi signifikan manajemen mutu terhadap kepuasan kerja pada Guru SMA Negeri 1 mengwi, 3) terdapat determinasi lingkungan kerja dengan kepuasan kerja pada Guru SMA Negeri 1 mengwi, 4) terdapat determinasi komitmen kerja dengan kepuasan kerja pada Guru SMA Negeri 1 mengwi, dan 4) terdapat determinasi secara simultan antara gaya kepemimpinan kepala sekolah, manajemen mutu, lingkungan kerja, dan komitmen kerja terhadap kepuasan kerja pada Guru SMA Negeri 1 mengwi.

Penelitian ini bertujuan untuk mengetahui besarnya kontribusi gaya kepemimpinan kepala sekolah, manajemen mutu, lingkungan kerja, dan komitmen kerja terhadap kepuasan kerja pada Guru SMA Negeri 1 mengwi secara terpisah maupun simultan.

Pengujian hipotesis dalam penelitian menggunakan teknik analisis regresi. Untuk menguji hipotesis pertama, kedua, dan ketiga digunakan teknik analisis regeresi sederhana, sedangkan untuk keempat digunakan teknik analisis regresi ganda dan korelasi parsial. Untuk mengetahui kuat lemahnya hubungan yang terjadi antara variabel bebas dengan variabel terikat digunakan korelasi product moment.

\section{HASIL PENELITIAN DAN PEMBAHASAN}

Berdasarkan uji normalitas data, diperoleh hasil bahwa semua data yaitu gaya kepemimpinan kepala sekolah, manajemen mutu, lingkungan kerja dan komitmen kerja terhadap kepuasan kerja berdistribusi normal dengan harga dari $p=0,179-0,200$ atau $p>0,05$. Sedangkan untuk pengujian linieritas menggunakan bantuan SPSS 16.0 dengan $p>$ 0,05 berarti semua variable mempunyai hubungan linier. Dari uji multikolinieritas diperoleh data koefisien korelasi dari 0,304 sampai 0,600 , semuanya dibawah 0,800 berarti tidak terjadi multikolinieritas. Uji heteroskedastisitas diperoleh hubungan $Y$ atas $X_{1}, X_{2}, X_{3}, x_{4}$ tidak ada pola yang jelas, serta titik-titik menyebar di atas dan di bawah angka 0 pada sumbu $Y$, maka tidak terjadi heteroskedastisitas. Sedangkan dari uji autokurelasi diperoleh koefisien Durbin-Watson besarnya 2,560 mendekati 2 artinya tidak terjadi autokorelasi.

Mengacu pada uji prasyarat, yakni uji normalitas sebaran data, uji linieritas, uji multikolinieritas, uji autokorelasi, dan uji heterokedastisitas, dapat disimpulkan bahwa data dari semua data memenuhi syarat yaitu data normal, semua data mempunyai hubungan linier, tidak terjadi multikolinieritas, tidak terjadi heteroskedastisitas, dan tidak terjadi autokorelas. Dengan demikian uji hipotesis dengan analisis regresi dapat dilakukan.Berdasarkan hasil pengujian hipotesis menggunakan analisis regresi dan determinasi menggunakan bantuan program SPSS versi 16.00 diperoleh hasil seperti tabel 1, sebagai berikut. 
Tabel 1. Ringkasan Hasil Analisis Data Hubungan antar Variabel

\begin{tabular}{|l|l|c|c|c|}
\cline { 2 - 5 } \multicolumn{1}{c|}{} & Persamaan Garis Regresi & $\begin{array}{c}\text { Koefisien } \\
\text { Korelasi }\end{array}$ & $\begin{array}{c}\text { Determina } \\
\text { si } \\
(\%)\end{array}$ & $\begin{array}{c}\text { Sumbangan } \\
\text { Efektif (SE) (\%) }\end{array}$ \\
\hline $\mathrm{X}_{1}$ dengan $\mathrm{Y}$ & $\hat{\mathrm{Y}}=57,833+0,634 \mathrm{X}_{1}$ & 0,631 & 39,90 & 17,20 \\
\hline $\mathrm{X}_{2}$ dengan $\mathrm{Y}$ & $\hat{\mathrm{Y}}=18,865+0,820 \mathrm{X}_{2}$ & 0,786 & 61,80 & 31,70 \\
\hline $\mathrm{X}_{3}$ dengan $\mathrm{Y}$ & $\hat{\mathrm{Y}}=71,116+0,667 \mathrm{X}_{3}$ & 0,607 & 36,90 & 11,70 \\
\hline $\mathrm{X}_{4}$ dengan $\mathrm{Y}$ & $\hat{\mathrm{Y}}=62,028+0,713 \mathrm{X}_{4}$ & 0,650 & 42,20 & 16,50 \\
\hline $\begin{array}{l}\mathrm{X}_{1}, \mathrm{X}_{2} \text {,dan } \mathrm{X} \\
\text { dengan } \mathrm{Y}\end{array}$ & $\begin{array}{l}\hat{\mathrm{Y}}=-18,456+0,273 \mathrm{X}_{1}+ \\
0,420 \mathrm{X}_{2}+0,211 \mathrm{X}_{3}+0,278 \\
\mathrm{X}_{4}\end{array}$ & 0,877 & 76,90 & - \\
\hline Keterangan & Signifikan dan linier & Signifikan & - & - \\
\hline
\end{tabular}

Keterangan :

$\mathrm{X}_{1}$ = Skor gaya kepemimpinan kepala sekolah

$\mathrm{X}_{2}=$ Skor manajemen mutu

$\mathrm{X}_{3}=$ Skor lingkungan kerja

$\mathrm{X}_{4}=$ Skor komitmen kerja

$\mathrm{Y}=$ Skor kepuasan kerja

Temuan pertama dari tabel 1 menunjukkan bahwa terdapat determinasi yang signifikan antara gaya kepemimpinan kepala sekolah terhadap kepuasan kerja melalui persamaan regresi $\hat{Y}=57,833+0,634 X_{1}$ dengan kontribusi sebesar 39,90\%. Dengan kata lain bahwa makin baik gaya kepemimpinan kepala sekolah makin baik pula kepuasan kerja guru. Variabel gaya kepemimpinan kepala sekolah memberikan sumbangan efektif (SE) sebesar 17,20 \% terhadap kepuasan kerja di SMA Negeri 1 Mengwi, sedangkan sisanya ditentukan oleh variabel lain.

Gaya kepemimpinan merupakan suatu pola perilaku seseorang pemimpin yang khas pada saat mempengaruhi anak buahnya, apa yang dipilih oleh pemimpin untuk dikerjakan, cara pemimpin bertindak dalam mempengaruhi anggota kelompok membentuk gaya kepemimpinannya. Secara teoritis telah banyak dikenal gaya kepemimpinan, namun gaya mana yang terbaik tidak mudah untuk ditentukan.

Gaya kepemimpinan seseorang dalam hal ini kepala sekolah sangat mempengaruhi kondisi kerja, akan berhubungan dengan bagaimana bawahan (guru) menerima suatu gaya kepeminpinan yang diwujudkan dalam bentuk senang atau tidak (Suroso, 2002). Gaya kepemimpinan tertentu juga dapat menyebabkan peningkatan kepuasan kerja atau sebaliknya dapat menurunkan kepuasan kerja. Oleh karena itu, untuk mempertahankan dan meningkatkan kinerja guru diperlukan seorang pemimpin yang menggunakan gaya kepemimpinan situasional, yaitu pemimpin yang mernpunyai kemampuan pribadi dan mampu membaca keadaan bawahan dalam hal ini guru serta lingkungannya (Hersey dan Blanchard, 2000). Kematangan bawahan akan berkaitan langsung dengan gaya kepemimpinan yang tepat untuk diterapkan.

Kepemimpinan kepala sekolah sangat menentukan mutu, tanpa kepemimpinan yang baik proses peningkatan mutu tidak dapat dilakukan dan diwujudkan. Keutamaan pengaruh (influence) kepemimpinan kepala sekolah bukanlah semata-mata berbentuk instruksi, melainkan lebih merupakan motivasi atau pemicu (trigger) yang dapat memberi inspirasi terhadap para guru dan karyawan, sehingga inisiatif dan kreatifitasnya berkembang secara optimal untuk meningkatkan kepuasan kerjanya. 
Dari uraian diatas, maka dugaan yang menyatakan bahwa gaya kepemimpinan kepala sekolah berdeterminasi terhadap kepuasan kerja guru terbukti dalam penelitian ini. Hal ini sesuai dengan penelitian yang dilakukan oleh Ni Putu Librawati (2013) dengan judul tesis "Analisis Pengaruh Sikap Profesional, Iklim Kerja Sekolah, dan Gaya Kepemimpinan Kepala Sekolah terhadap Kinerja Guru SMP Negeri di Kecamatan Sukawati". Dari hasil penelitian diperoleh bahwa terdapat pengaruh yang positif dan signifikan antara gaya kepemimpinan

Kepala Sekolah terhadap kinerja guru melalui persamaan garis regresi $\hat{\mathrm{Y}}=47,462+0,909$ $\mathrm{X}_{3}$ dengan kontribusi sebesar $46,3 \%$ dan sumbangan efektif sebesar $24,1 \%$

Temuan kedua menunjukkan bahwa terdapat determinasi yang signifikan antara manajemen mutu terhadap kepuasan kerja melalui persamaan regresi $\hat{Y}=18,865+0,820$ $\mathrm{X}_{2}$ dengan $\mathrm{F}_{\text {reg }}=110,018(\mathrm{p}<0,05)$ dengan kontribusi sebesar $61,80 \%$. Dengan kata lain bahwa makin tinggi skor pencapaian manajemen mutu makin tinggi kepuasan kerja. Variabel manajemen mutu memberikan sumbangan efektif (SE) sebesar 31,70\% terhadap kepuasan kerja di SMA Negeri 1 Mengwi, sedangkan sisanya ditentukan oleh variabel lain.

Manajemen mutu adalah aspek dari seluruh fungsi manajemen yang menetapkan dan melaksanakan kebijakan mutu. Pencapaian mutu yang diinginkan memerlukan kesepakatan dan partisipasi seluruh anggota organisasi, sedangkan tanggung jawab manajemen mutu ada pada pimpinan puncak. Untuk melaksanakan manajemen mutu dengan baik dan menuju keberhasilan, diperlukan prinsip-prinsip dasar yang kuat.

Manajemen mutu dalam pendidikan merupakan cara dalam mengatur semua sumber daya pendidikan, yang diarahkan agar semua orang yang terlibat di dalamnya melaksanakan tugas dengan penuh semangat dan berpartisipasi dalam perbaikan pelaksanaan pekerjaan sehingga menghasilkan jasa yang sesuai bahkan melebihi harapan pelanggan. Dengan bekerja dengan penuh semangat, maka kinerja yang dihasilkan juga akan meningkat. Dapat dikatakan bahwa manajemen mutu akan mampu meningkatkan kinerja guru. Makin baik manajemen mutu yang diterapkan dari suatu organisasi, maka makin baik pula kinerja guru di sekolah tersebut.

Hasil penelitian menemukan bahwa manajemen mutu berkontribusi terhadap kepuasan kerja guru di SMA Negeri 1 Mengwi terbukti dalam penelitian ini. Hal ini sesuai dengan penelitian yang dilakukan oleh Luh De Liska (2012), mengadakan penelitian dengan judul "Faktor - Faktor Strategik Yang Mempengaruhi Pengembangan Kinerja Guru ( Studi Tentang Pengaruh Perilaku Kepemimpinan Kepala Sekolah, Budaya Organisasi dan Manajemen Mutu Terhadap Kinerja Guru di SMA Negeri dan Swasta Kecamatan Kuta Kabupaten Badung ). Penelitian ini menghasilkan bahwa terdapat kontribusi yang positif dan signifikan antara manajemen mutu terhadap kinerja guru guru melalui persamaan garis regresi $\hat{\mathrm{Y}}=35,049+0,695 \mathrm{X}_{3}$ dengan kontribusi sebesar $55,8 \%$ dan sumbangan efektif sebesar $33,2 \%$

Temuan ketiga menunjukkan bahwa terdapat determinasi yang signifikan antara lingkungan kerja terhadap kepuasan kerja melalui persamaan regresi $\hat{Y}=71,116+0,667 X_{3}$ dengan kontribusi sebesar 36,90 \%. Dengan kata lain bahwa makin tinggi skor pencapaian lingkungan kerja makin baik kepuasan kerja. Variabel lingkungan kerja memberikan sumbangan efektif $(\mathrm{SE})=11,70 \%$ terhadap kepuasan kerja di SMA Negeri 1 Mengwi, sedangkan sisanya ditentukan oleh variabel lain.

Syaiful Sagala (2004: 61) mengemukakan bahwa lingkungan kerja sekolah adalah sekelompok faktor-faktor yang mempengaruhi sekolah, seperti masyarakat sekolah, masyarakat di sekitar sekolah, pemerintah yang memfasilitasi sekolah, pelayanan belajar dan hal-hal lain yang berkaitan dengan manajemen sekolah. Lingkungan kerja sekolah sebagai layanan pendidikan dipengaruhi oleh faktor internal dan eksternal. Karena itu, kepala sekolah sebagai manajer pendidikan dituntut untuk mampu memberdayakan seluruh potensi sekolah, kemudian bertanggung jawab atas operasional keseluruhan potensi sekolah 
dan meningkatkan mutu layanan belajar dan mutu hasil belajar yang berorientasi kepada pamakai, baik siswa, masyarakat, pemerintah, maupun industri atau dunia usaha.

Lingkungan kerja merupakan suatu kondisi atau keadaan yang mempunyai pengaruh yang besar terhadap organisasi apakah itu mencakup pengaturan tempat kerja seperti penerangan, kebersihan, sirkulasi udara, pengaturan warna, kebisingan, dan keamanan kerja, baik itu langsung maupun tidak langsung mempengaruhi kepuasan kerja guru.

Dari hasil penelitian diperoleh lingkungan kerja berdeterminasi terhadap kepuasan kerja di SMA Negeri 1 Mengwi Hal ini sesuai dengan penelitian yang dilakukan oleh Endang, Setiawati (2012) dengan judul "Kontribusi Lingkungan Kerja, Kepemimpinan Kepala Madrasah Dan Etos Kerja Terhadap Kinerja Guru MAN Se Kabupaten Jembrana". Hasil penelitian ini memperoleh Lingkungan Kerja terhadap Kinerja Guru dengan kontribusi sebesar $75,4 \%$, sumbangan efektif (SE) sebesar $21 \%$, dan determinasi parsial sebesar $75,4 \%$

Temuan keempat menunjukkan bahwa terdapat determinasi yang signifikan antara komitmen kerja terhadap kepuasan kerja melalui persamaan regresi $\hat{Y}=62,028+0,713 X_{4}$ dengan kontribusi sebesar 42,20 \%. Dengan kata lain bahwa makin tinggi skor pencapaian komitmen kerja makin baik kepuasan kerja. Variabel komitmen kerja memberikan sumbangan efektif $(\mathrm{SE})=16,50 \%$ terhadap kepuasan kerja di SMA Negeri 1 Mengwi, sedangkan sisanya ditentukan oleh variabel lain.

Komitmen kerja dalam proses pembelajaran adalah berlangsungnya proses belajar mengajar di kelas yang merupakan inti dari kegiatan pendidikan di sekolah. Dalam hal ini kemampuan kerja guru dalam mengelola proses pembelajaran adalah kesanggupan atau kecakapan para guru dalam menciptakan suasana komunikasi yang edukatif antara guru dan peserta didik yang mencakup segi kognitif, afektif, dan psikomotor.

Empat kompetensi utama yang dimiliki oleh guru profesional (Sudarwan Danin.2011:8689), pertama kompetensi pedagogis. Kompetensi ini terdiri dari lima subkompetensi, yaitu : memahami siswa secara mendalam, merancang pembelajaran, termasuk memahami landasan pendidikan untuk kepentingan pembelajaran. Melaksanakan pembelajaran, merancang dan melaksanakan evaluasi pembelajaran, dan mengembangkan siswa untuk mengaktualisasi berbagai potensinya. Kompetensi inilah yang dikenal dengan kemampuan guru dalam manajemen kelas, dimana guru harus mengoptimalisasikanpotensi sumber daya kelas, baik yang fisikal maupun situasional.

Hasil penelitian memperoleh komitmen kerja berdeterminasi terhadap kepuasan kerja guru di SMA Negeri 1 Mengwi. Hal ini sesuai dengan penelitian yang dilakukan oleh Ni Luh Putu Labasariyani (2011) dengan judul komitmen guru terhadap tugas profesi ditinjau dari latar belakang pendidikan, pengalaman dalam pelatihan, dan konsep diri Guru SMK PGRI 4 denpasar.

Temuan kelima menunjukkan bahwa terdapat determinasi yang signifikan secara bersama-sama antara gaya kepemimpinan kepala sekolah, manajemen mutu, lingkungan kerja dan komitmen kerja terhadap kepuasan kerja melalui persamaan garis regresi $\hat{\mathrm{Y}}=-$ $18,456+0,273 X_{1}+0,420 X_{2}+0,211 X_{3}+0,278 X_{4}$ dengan $F_{\text {reg }}=54,023(p<0,05)$. Ini berarti secara bersama-sama variabel gaya kepemimpinan kepala sekolah, manajemen mutu, dan lingkungan kerja dapat menjelaskan tingkat kecenderungan kepuasan kerja di SMA Negeri 1 Mengwi. Dengan kata lain bahwa gaya kepemimpinan kepala sekolah, manajemen mutu, dan lingkungan kerja berhubungan dengan kepuasan kerja di SMA Negeri 1 Mengwi. Dari hasil analisis juga diperoleh koefisien korelasi ganda sebesar 0,877 dengan $p<0,05$. Ini berarti, secara bersama-sama gaya kepemimpinan kepala sekolah, manajemen mutu, dan lingkungan kerja berkontribusi positif dengan kepuasan kerja di SMA Negeri 1 Mengwi sebesar $76,90 \%$ artinya sekitar $76,90 \%$ variasi dalam variabel kepuasan kerja dapat dijelaskan oleh variabel gaya kepemimpinan kepala sekolah, manajemen mutu, dan lingkungan kerja sedangkan sisanya ditentukan oleh variabel lain yang tidak diteliti. Makin 
tinggi gaya kepemimpinan kepala sekolah, makin baik manajemen mutu, dan makin tinggi lingkungan kerja serta komitmen kerja, makin tinggi pula kepuasan kerja. Bila dilihat koefisien determinasi keempat variabel tersebut, tidak sepenuhnya bahwa variabel-variabel tersebut dapat memprediksikan kepuasan kerja

\section{PENUTUP}

Berdasarkan analisis dan pembahasan seperti yang telah dipaparkan pada bagian sebelumnya, maka dapat disimpulkan beberapa hal sebagai berikut.

Pertama, terdapat determinasi yang signifikan antara gaya kepemimpinan kepala sekolah terhadap kepuasan kerja SMA Negeri 1 Mengwi melalui persamaan garis regresi $\hat{Y}$ $=57,833+0,634 X_{1}$ dengan sumbangan efektif sebesar $17,20 \%$.

Kedua, terdapat determinasi yang signifikan antara manajemen mutu terhadap kepuasan kerja SMA Negeri 1 Mengwi melalui persamaan garis regresi: $\hat{Y}=18,865+0,820$ $\mathrm{X}_{2}$ dengan sumbangan efektif sebesar $31,70 \%$.

Ketiga, terdapat determinasi yang signifikan antara lingkungan kerja terhadap kepuasan kerja SMA Negeri 1 Mengwi melalui persamaan garis regresi $\hat{Y}=71,116+0,667$ $\mathrm{X}_{3}$ dengan sumbangan efektif sebesar $11,70 \%$.

Keempat, terdapat determinasi yang signifikan antara komitmen kerja terhadap kepuasan kerja SMA Negeri 1 Mengwi melalui persamaan garis regresi $\hat{Y}=62,028+0,713$ $\mathrm{X}_{4}$ dengan sumbangan efektif sebesar $16,50 \%$.

Kelima, terdapat determinasi yang signifikan secara bersama-sama antara gaya kepemimpinan kepala sekolah, manajemen mutu, lingkungan kerja, dan komitmen kerja terhadap kepuasan kerja SMA Negeri 1 Mengwi melalui persamaan garis regresi $\hat{\mathrm{Y}}=-$ $18,456+0,273 X_{1}+0,420 X_{2}+0,211 X_{3}+0,278 X_{4}$ dengan kontribusi sebesar 76,90\%.

Berdasarkan kesimpulan dan implikasi penelitian yang telah dipaparkan di atas, maka dapat disarankan beberapa hal yaitu sebagai berikut.

Bagi Guru SMA Negeri 1 Mengwi adalah (1) mengikuti gaya kepemimpinan kepala sekolah, (2) berusaha secara maksimal meningkatkan manajemen mutu, (3) berusaha menciptakan lingkungan kerja yang kondusif, (4) berusaha secara maksimal meningkatkan komitmen kerja, dan (5) bersedia menerima kritik dari berbagai pihak guna meningkatkan kinerja.

Bagi Kepala SMA Negeri 1 Mengwi adalah: (1) berusaha secara maksimal meningkatkan mutu gaya kepemimpinan, manajemen mutu, lingkungan kerja, dan komitmen kerja, (2) meningkatkan sarana dan prasarana sekolah, (3) memiliki komitmen yang tinggi untuk mencerdaskan kehidupan bangsa, (4) penciptaan lingungan kerja yang kondusif, dan (4) bersedia menerima kritik.

Bagi kepada praktisi dan akademisi adalah perlu diadakan penelitian lebih lanjut tentang berbagai faktor yang diduga berkontribusi terhadap kepuasan kerja di SMA Negeri 1 Mengwi. Dengan dilibatkannya variabel-variabel lain tersebut akan menambah referensi dan dapat dimanfaatkan sebagai pijakan untuk melakukan perbaikan-perbaikan guna meningkatkan kepuasan kerja di SMA Negeri 1 Mengwi.

\section{DAFTAR RUJUKAN}

Endang, Setiawati. 2012. Kontribusi Lingkungan Kerja, Kepemimpinan Kepala Madrasah Dan Etos Kerja Terhadap Kinerja Guru MAN Se Kabupaten Jembrana. E-Journal Vol. 3 No.1. Pascasarjana Universitas Pendidikan Ganesha.

Hersey, Paul dan Kenneth. H. Blanchard.2000. Manajemen Perilaku Organisasi : Pendayagunaan Sumber Daya Manusia. Terjemahan Agus Dharma,Erlangga: Jakarta. 
Labasariyani Ni Luh Putu. 2011. komitmen guru terhadap tugas profesi ditinjau dari latar belakang pendidikan, pengalaman dalam pelatihan, dan konsep diri guru smk pgri 4 denpasar. Jurnal Vol 2. Pascasarjana Universitas Pendidikan Ganesha.

Librawati. 2013. Analisis Pengaruh Sikap Profesional, Iklim Kerja Sekolah, dan Gaya Kepemimpinan Kepala Sekolah terhadap Kinerja Guru SMP Negeri di Kecamatan Sukawati. Journal. e-Journal Vol 4 Program Pascasarjana Universitas Pendidikan Ganesha.

Liska, Luh De. 2012. Faktor - Faktor Strategik Yang Mempengaruhi Pengembangan Kinerja Guru ( Studi Tentang Pengaruh Perilaku Kepemimpinan Kepala Sekolah, Budaya Organisasi dan Manajemen Mutu Terhadap Kinerja Guru di SMA Negeri dan Swasta Kecamatan Kuta Kabupaten Badung ). Tesis. Program Pascasarjana Universitas Pendidikan Ganesha.

Sedarmayanti. 1996. Tata Kerja Dan produktivitas Kerja, Suatu Tinjauan Dari Aspek Ergonomi atau Kaitan Antara Manusia dan Lingkungan Kerjanya. Cetakan Pertama. Penerbit Mandar Manju : Bandung.

Sudarwan Danim. 2011. Motivasi Kepemimpinan dan Efektivitas Kelompok. Jakarta: Rineka Cipta

Sudjana, dkk. 1989. Pedoman Praktek Mengajar. Bandung; Depdikbud.

Suroso, 2002. In Memorian guru. Yogyakarta : Jendela.

Syaiful, Sagala dan Anwar, Qomari. 2004. Profesi Jabatan Kependidikan dan Guru Sebagai Upaya Menjamin Kualitas Pembelajaran. Jakarta: Uhamka Press.

Steers, M Richard. (1985). Efektivitas Organisasi Perusahaan. Jakarta: Erlangga.

Thoha, Miftah, 1995. Prilaku Organisasi Konsep dasar dan aplikasinya. Jakarta:PT Raya Grafindo . 